\title{
Character Education Values in the Youth Pledge History Learning Materials
}

\author{
Johan Setiawan \\ Graduate School \\ Universitas Negeri Yogyakarta \\ Yogyakarta, Indonesia \\ johansetiawan.2017@student.uny.ac.id
}

\author{
Aman \\ Graduate School \\ Universitas Negeri Yogyakarta \\ Yogyakarta, Indonesia \\ aman@uny.ac.id
}

\begin{abstract}
This paper was based on the background of the problem about the decline of the nation's, especially students. History education has a vital role in the formation of character, because through history teaching can inherit the values available in a historical event. The method used in this research was descriptive qualitative research method with literature study. The result of this research was with the pledge youth II on October 28, 1928, which was a concrete formality of the reality of national consciousness manifested through the youth congress that issued a statement of one land, one nation and one language. Additionally, character values that were contained in that learning material were the love of homeland, communicative, tolerance, and national spirit as well as nationalism. Those character values should be able to be actualized by the students in their life in the present and in the future.
\end{abstract}

Keywords- Learning material, Character, Value, Education, The youth pledge.

\section{INTRODUCTION}

The youth pledge on October 28, 1928 showed determination and desire to build unity and oneness because it showed awareness towards diversity and cultural, religions, ethnicities and tribes diversity that ultimately lead to the struggle for Indonesian independence in the future. "Indonesia is a unitary state which is multi-ethnic, multi-cultural, multireligious, and other diversity that is shown by the motto of Bhineka Tunggal Ika (Unity in Diversity). A slogan that has deep philosophical meaning, which become the adhesive of Indonesian society in a unity territory of Indonesia, one homeland, one nation and one language, which is born by the event of Sumpah Pemuda (the Oath of the youth) [1].

Indonesia often experienced events that threaten the unity and oneness of the nation. "We still remember, Indonesia was confronted with a range of this sort of communal conflicts. Examples include Christian-Muslim bloodshed in Ambon in the province of Maluku (January 1999), and the city of Poso in the province of Central Sulawesi (December 1998). The province of North Maluku (August 1999) witnessed atrocious inter-religious warfare between Christians and Muslims and interethnic violence among Muslims. Inter-ethnic riots between Dayaks and Madurese raged in Central (February 2001) and West Kalimantan (January
1998) and Malay-Madurese violence affected West Kalimantan (February 1999) [2].

In fact, the event was not supposed to happen if there was mutual respect and the willingness to uphold the sense of unity. The event marked a faded sense of unity and oneness among children of the nation. There were no mutual tolerance and respect for differences anymore, indicating that there was a decline in the values of the sense of unity among people.

The fading of the nation's unity values in this globalization era for the younger generation, especially the students at the secondary school are marked by the lack of love to the country, tolerance, hard work, lack of nationalism, disrespect for diversity and differences, decrease of solidarity, do not fully somprehend the content of the youth that contains one land, one nation, and one language.

The decrease of the youth pledge's values can be a real threat for the future younger generation with the fading of the values that becomes the basis of the love to the country. For example, many younger generation including students who do not understand the Indonesian historical hassle crossbars where one of them was marked with the youth pledge. Less understanding about history and the fading of the meaning of the youth pledge can affect the students' current character values.

One of the ways to solve the problems above is through education since education becomes the most appropriate media to solve the problems that often occur nowadays because its role is vital in character shaping. One of the important parts in education to engraft the concept of character is through history subject.

History is one of the subjects that affect the building of national character-based education. In the history subject that explains events collectively from a community or society that besome one of the aspects in national personality shaping. Starting from collective individual memory that is directed into one goal that is national identity awareness through the nation's history. The youth pledge learning material as one of the results of unity and oneness and the goal is to reach independent Indonesia. 
This event contains character education values; it is in line with 2013 curriculum that points out character education. There are 18 values that are contained in character education, those values are the values of "religious, tolerance, honest, discipline, hardwork, creative, independent, curiosity, democratic, love the nation, nationess, respecting achievement, friendly, loving peac, love reading, care to the environment, social care, and responsibility"[3].

Based on the explanation of background above, therefore history learning materials that can engraft character values in learning process are needed, one of them is through the youth pledge learning material in engrafting character education values. It is hoped that this paper can give a contribution to knowledge especially in history subject about the importance of educational process in transforming character values.

\section{MATERIAL AND METHODOLOGY}

The method that was used in this research was descriptive qualitative method, the definition of descriptive qualitative is data that is in form of information, elaboration in form of prose ans then is linked with other data to get clarity about a truth or the opposite, so that a new image or contain an available image [4]. This research is a literature study, the data was gathered through primary or secondary sources where content analysis was done according to the research aims.

\section{RESULT AND DISCUSSION}

\section{A. The Concept of Character Education}

Education is a conscious effort and has been planned in the process of guidance and learning for individuals in order to grow into a responsible, creative, independent, knowledgeable, healthy and noble person. Based on that, it is necessary to have a learning process that contains the character values, so it is hoped that it will be able to grow the character of the students

Speaking about character, character is the basic value that builds someone's personality, formed either by the influence of heredity and the influence of the environment, which distinguishes him/her from others, and is manifested in his/her attitude and behavior in everyday life [5]. The term character possesses two definitions. First, if some one behave badly, violent or greedy, that person is surely manifested bed attitude. In the other hand, if someone acts honestly, love to help, of course that person manifested noble character. Second, the terms character is closely related to personality, someone can be called as someone with character if his/her attitude is in accordance wth moral norm [6]

However, according to Marzuki in Agus Wibowo's book, character is identical to moral [7], so that character is the universal values of human behavior which encompasses all human activities, whether in relation to God, with oneself, with fellow human beings, as well as with the environment, manifested in thoughts, attitudes, feelings, words and actions based on norms, religious norms, law, manner, culture, and customs.

According to the experts above, it can be concluded that the character is a behavior that exists within someone's personality in the form of good and bad behavior, which can distinguish him/her with others and done in behavior that can and cannot be seen by others in everyday life.

From the concept of education and character as mentioned above, the concept of character education appears. Character education itself according to Thomas Lickona in abook by Retno Listyarti is about becominga character school, where school is the best place to engraft character. "Lickona also explained that one of the main tasks of school as moral educator is to help students to understand that fact and and moral action correctly" [8]. "Where in character education process character is based on cognitive, affective, and psycomotoric area"[9].

According to Muchlas, character education is a guidance giving to the students to become a whole human with character in the dimension of heart, mind, feeling and wish [10]. Additionally, Dharma Kusuma defined character education as an effort to educate children to be able to make correct decision and to practice it in daily life so that they can give positive contribution to their surroundings [11].

According to the experts above, it can be concluded that characters education is an effort that is done by a teacher in a school to his/her students that covers moral and character education and many others that are hoped to be the students' hand-grip in daily social intercourse to do good things and she/he acknowledges bad behavior so that she/he can choose shich thing is bad in his/her daily life.

\section{B. Values in Character EducationThe Concept of}

According to Dictionary and Related Sciences in Kaelan value is an ability that is believed in a thing to satisfy human [12]. Character of a thing that attracts someone or a group, the thing or object here is value in character education. Walter G. Everest in Kaelan contended that one of the types of values is nature character, nature that is character [12]. Values that are going to be transformed in the learning process are:

1) Religious is obedient behavior and attitude in implementing the teachings of religion that the people follow, appreciate the time of other religious worship and live in harmony with the followers of other religions.

2) Honest is behavior based on the effort to make himself/herself a person who can always be trusted in words, actions, and deed.

3) Tolerance is attitude and behavior that appreciate the difference in terms of religion, belief, ethnic, 
linguistic, race, ethnic, and opinion consciously and openly. In addition, it can live quietly amid differences that exist.

4) Discipline is consistent habit and action of any form of rules or order.

5) Hard work is attitude and behavior that shows genuine efforts in completing various tasks, problems, work, and obstacles in the best way possible.

6) Creative is attitude and behavior that always reflects the idea of innovation in solving various problems, so always find new ways and even can create new results better than ever.

7) Independent is attitude and behavior that is not dependent on others in completing various tasks and problems. However, this does not mean collaboration should not be collaborative, but it should not be putting the duties and responsibilities to others.

8) Democratic is attitude and way of thinking that reflects equality of rights and duties fairly and equitably between himself and others.

9) Curiosity is the way of thinking, ready and behavior that reflects the curiosity and curiosity of everything that has ever been seen, heard, or felt and studied in depth.

10)The spirit of nationalism and nationalism are attituded and actions that places the interests of the nation and state on the personal or individual interests and groups.

11)Love the homeland is the attitude and behavior that reflects the pride, loyalty, care and high appreciation of the language, culture, economy, politics and so on, so it is not easy to accept the offer of another nation that can harm the nation it self

12)Respecting achievement is open attitude toward the achievement of others and acknowledges lack of self without reducing the spirit of achievement is higher, (m) Communicative, is attitudes and actions that are open to others through polite communication to create a good cooperation between himself and others.

13)Loving peace is attitudes and behaviors that reflect a peaceful, safe, calm, and comfortable atmosphere for his or her presence in a particular community or community.

14)Love reading is the habit of being free to spend time in particular to read various information, whether books, journals, magazines, newspapers, and so on, giving rise to policies for him/her.

15) Care for the environment is the attitude and actions that always try to maintain and preserve the surrounding environment.

16) Social care is attitudes and actions that reflect the concern for others and the community in need, and

17) Responsibility is attitude and behavior of a person in carrying out duties and obligations, whether related to self, social, society, nation, state and religion [13].
Thus, the eighteen characters values that must be internalized in the school into all subjects one of them through learning history designed to be active and fun. It is expected that through one of the existing materials in history lessons on the history of the youth oath that contain the values of characters to be actualized and transformed to learners in a learning process.

\section{The Potential of History Learning Material in Character}

History subjects taught in schools have a strategic goal in shaping the character and dignity of the nation, because it has a sense of nationality and love of the country. The material in a typical and highly valued history lesson will potentially be introduced to learners about the nation and its aspirations in the past. It will be able to develop the potential within the learners to be able to recognize the values of the nation that is fought for, maintained, and even developed for the life of the present and the future.

Historical materials provide information about the success and the failure of the nation in answering the challenges of the times. These successes and failures are important lessons to understand. With such material nature, in developing the function of education as history "bank of examples for solving present problems and chartering future action [14]. Dissolved by the state of the nation and the limitations of education policy to put knowledge above all else. In learning history, an important function to learn it in order to know our identity as a nation of Indonesia. Losing identity means losing the nation's existence.

Historical education materials will be able to build collective memory of learners if there is a strong identification process of historical events studied. Therefore, there are several criteria in choosing historical education materials:

First, a strong identification will occur if learners feel the struggle of previous generations to build the Indonesian nation can be known from the available historical sources. It is simply reflected in the historical events of a governmental and cultural unit. Government units may be in provincial or district units. The cultural unit is represented by the tribe. Of course, these two criteria should not be used separately, or both must be met.

Second, important events for the Indonesian nation since the start of the Indonesian national uprising, which began in 1908, pledged the youth pledge in 1928 until Indonesian independence. Because this period was full of people-centered struggles and struggle leaders were not chosen because of blood but more on their ability, the direction of struggle was clearer and more straightforward during the formation of Indonesia and the nation. 
Third, it is necessary to balance the historical events that learners learn between events occurring in their area of residence (within the province unit or below) with events occurring in other areas

Fourth, the organization of historical education materials at the start of the events that occur in the immediate environment of the learners to the national and international level. Historical education materials should give the learner the opportunity to know his/her closest community (from historical reviews) to his people and humankind (history of the city/county, provincial history, national history) [15].

From these criteria in the selection of material that has been described above, the researchers were interested to examine the material about the youth pledge that was one of the important events for Indonesian nation. These events contain many character values that will be transformed to learners, especially high school students. These character values can be actualized in life.

\section{The Youth Pledge History Learning Materials}

The Youth Pledge Event is a concrete formality of the reality of national consciousness manifested through the youth congress. From the youth pledge, initiated by youth from various regional representations throughout Indonesia succeeded in uniting common views and ideals through unity that wants the achievement of an independent Indonesia.

In order to create unity and togetherness among youth organizations that already exist, some meetings were initiated to reach consensus until $15^{\text {th }}$ of November 1925 the youth congress was held in order to form the committee of agreement implementation. From April 30-May 2, 1926 that was called as Youth Congress I. The Youth Congress was presented by representations from Jong Java, Jong Minahasa, Jong Ambon, Pemuda Indonesia, Jong Batak, PPPI and many others.

The congress was held by Muhammad Tabrani who, in his opening speech said"..we are all Javanese, Sumatran, Minahasan, Ambonese, and many others, through history, we are mande into people who have to lend our hands for each other, when we reach our goals, that is Indonesian independence, the motherland that we love" [16].

The result of that assembly formulated some basis of communal thought such as: (1) Indonesian independence from colonizer is a goal of all Indonesian youth, and (2) The whole youth organization is intended to achieve unity. From the Youth Congress I, the youth keeps on trying to achieve unity in order to attain Indonesian independence.

"One of the meetings that has to be recorded in Indonesian history is the youth's meeting in April 23, 2017 that created a declaration that the goal of
Indonesian independence is the communal goal of Indonesian child" [16]. Until the organization of The Youth Congress II that was initiated by Indonesian Student Association (PPPI). The Youth Congress III was held from 26-28 October 1928 in Jakarta.

The committee of The Youth Congress II consisted of The Leader: Soegondo Djojopoespito (PPPI), Vice Leader: R.M. Djoko Marsaid (Jong Java), Secretary: Mohammad Jamin (Jong Sumateranen Bond), Treasurer: Amir Sjarifuddin (Jong Bataks Bond), Helper I: Djohan Mohammad Tjai (Jong Islamieten Bond), Helper II: R. Katja Soengkana (Pemoeda Indonesia), Helper III: Senduk (Jong Celebes), Helper IV: Johanes Leimena (yong Ambon), Helper V: Rochjani Soe'oed (Pemoeda Kaoem Betawi), and youth participant from many regions.

The resulf of the youth congress II that formulated communal agreement such as: (1) The youth pledge, (2) Indonesia Raya is the national anthem, (3) The red and white flag as the country's flag, (4) Indonesian independent has to be the goal of all Indonesian youth, (5) All youth organizations must be united in one single organization.

According to Emil in national heritage buildings said that youth declaration or that is known as the youth pledge is the unity of several regional youth organizations [17]. The content of The Youth Pledge is "we the sons and daughters of Indonesia, acknowledge one motherland, Indonesia, we the sons and daughters of Indonesia, acknowledge one nation, the nation of Indonesia, we the sons and daughters of Indonesia, respect the language of unity, Indonesia" [18].

Through the Youth Pledge, motherland, nation and language could be formed to unity. It was also through the youth pledge the struggle that was done by Indonesian nation was no longer done regionally, but it was done nationally so that independence could be attained. Now the spirit of the youth pledge must be actualized to the students so that oneness and unity of the Indonesian nation can be well maintained.

Additionally, the youth pledge can also increase respect with one another and value each other or is known as tolerance. From the history of the youth pledge, we can inherit the values of oneness and unity of nation and it was able to prove that differences could be united. The character values that consist in the history of the youth pledge can be implemented and applied in the present and in the future.

\section{E. Character Values in the Youth Pledge History Leraning Materials}

Referring to the of the youth pledge history learning materials and is linked to eighteen characters values. Therefore, the character values that are in that materials are tolerance, love the nation, spirit of patriotism and nationalism. 
The following are the explanation of character values that are in the youth pledge history learning materials:

1) Tolerance. Indonesian nation is known as a multicultural nation. The Diversity of religion, tribe, culture as well as language. The six religions that are officially acknowledged by Indonesian government, such as Islam, Christian, Catholic, Hindu, Buddha, and Konghucu. From all those six religions, Islam is the religion that are followed by most of the Indonesian people. Many kinds of tribe, culture, and language from Sabang to Merauke have decorated the beauty and richness of Indonesia. It can be achieved if there is respect and tolerance among differences, harmonization in life will be achieved. Therefore, tolerance action is highly essential to be actualized to the students. Since in their school community, the students consist of various tribe, culture, and religion.

2) Spirit of patriotism and nationalism. The event of the youth pledge shows attitude and actions of the youths who put the importance of nation and country over personal or individual and their community. Several youth organizations that are regionally formed, gather as one to discuss attitudes and actions that lead to the importance of nation and country. With high spirit of patriotism and nationalism attitude is marked by one land, one nation, and one language that is Indonesian.

3) Loving the country and motherland. In the event of the youth pledge there is a pledge of one motherland, one nation and one language that is Bahasa Indonesia. This is the realization of the love to the nation and motherland of the youths who still go through education must be loyal to the nation and Indonesian Country. We all do good things that are intended to the development of nation and Indonesian people.

4) Communicative. Attitude and action to other people through well-mannered and good communication will create good cooperation between him/herself with other people. It can be seen from how the Indonesian youths gather and share their thoughts in the youth congress. Without good communication between the youth organizations from various regions in Indonesia at that time, the youth congress would not be held, and the youth pledge would not be achieved. Therefore, the students must have good communication in interaction with peers in their life.

\section{CONCLUSIONS}

Character education is a guiding process that refers to the values of characters given by teachers to learners to become fully human by characterized by good character. The values contained in character education are religious, tolerant, honest, disciplined, hard work, creative, independent, curiosity, democratic, love homeland, nationality, appreciate achievement, friendly, love peace, love to read, social, and responsibility. Thus, the value of the characters is internalized in the school into one of the subjects through learning history.

History subjects taught in schools has a strategic goal in shaping the character and dignity of the nation, because it has a sense of nationality and love of the country. The Youth Pledge material is a concrete formality of the reality of national consciousness manifested through the youth congress. From the youth oath, pioneered by youth from various representatives of youth organizations throughout Indonesia, was succeeded in bringing together common ideals and ideals through unity of one land, one nation and one language, namely Indonesia. Referring to the youth pledge material and linked to eighteen characters values established by the Ministry of National Education through the Center for Research and Development of the Curriculum Center. Then the values of the characters contained in the material oath youth, among others, the attitude of tolerance, love of the homeland, the spirit of patriotism and nationalism.

\section{REFERENCES}

[1] Budiwati, N. "The Religious Life Harmony and The Nation's Integrity in History View," Jurnal Historia: International Journal of History Education 13 (2), 2012, pp. 275-294

[2] Adam, J. "Communal Violence, Forced Migration \& Social Change on The Island of Ambon, Indonesia," Belgia: Ghent University, 2010.

[3] Faza, A. "Pengajaran Sejarah sebagai Media Penanaman Wawasan Kebangsaan,” Wiyanata 8 (2), 2017, pp. 1-11.

[4] Subagyo, J. P. "Metode Penelitian: Dalam Teori dan Praktek”, Jakarta: Rineka Cipta, 2006.

[5] Samani, Muchlas \& Hariyanto. "Pendidikan Karakter", Bandung: PT. Remaja Rosdakarya, 2013.

[6] Gunawan, H. "Pendidikan Karakter: Konsep dan Implementasi.” Bandung: Alfabeta, 2014.

[7] Wibowo, A. "Manajemen Pendidikan Karakter Di Sekolah”. Yogyakarta: Pustaka Pelajar, 2013.

[8] Lickona, T. "Mendidik untuk Membentuk Karakter: Bagaimana Sekolah dapat Memberikan Pendidikan tentang Sikap Hormat dan Bertanggung Jawab”. Terjemahan Juma Abdu Wamaungo. 2015. Jakarta: Bumi Aksara, 1991.

[9] Listyarti, R. "Pendidikan Karakter dalam Metode Aktif, Inovatif \& Kreatif.” Jakarta: Penerbit Erlangga, 2012

[10] Samani, Muchlas \& Hariyanto. "Konsep dan Model Pendidikan Karakter.” Bandung: PT Remaja Rosdakarya, 2012.

[11] Kesuma, D. dkk. "Pendidikan Karakter: Kajian Teori dan Praktik di Sekolah”, Bandung: Remaja Rosdakarya, 2011.

[12] Kaelan, M.S. "Pendidikan Pancasila", Yogyakarta: Paradigma, 2008.

[13] Suyadi. "Strategi Pembelajaran Pendidikan Karakter" Bandung: PT Remaja Rosdakarya, 2015.

[14] Wineburg, S. "Historical Thinking and Other Unnatural Acts: Charting the Future of Teaching the Past," Philadelphia: Temple University Press, 2001.

[15] Hasan, S. H. "Pendidikan Sejarah untuk Memperkuat Pendidikan Karakter.” Paramita 22 (1), 2012, pp. 81-95.

[16] Yayasan Sumpah Pemuda. "Pemuda Indonesia dalam Dimensi Sejarah Perjuangan Bangsa”, Jakarta: Kurnia Esa, 1984. 
[17] Yayasan Gedung-gedung Bersejarah Jakarta. "Bunga Rampai Soempah Pemoeda", Jakarta: Balai Pustaka, 1989.
[18] Kartono \& Fatmawati, S. D. "Makna Sumpah Pemuda". Semarang: Bengawan Ilmu, 2010. 